Discussion Paper No. 10-007

\title{
You Can't Be Happier than Your Wife: Happiness Gaps and Divorce
}

Cahit Guven, Claudia Senik, and Holger Stichnoth

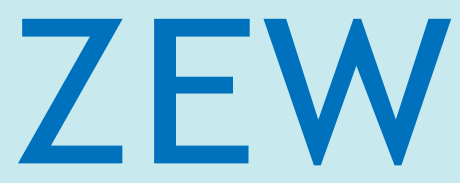

Zentrum für Europäische Wirtschaftsforschung $\mathrm{GmbH}$

Centre for European

Economic Research 
Discussion Paper No. 10-007

\title{
You Can't Be Happier than Your Wife: Happiness Gaps and Divorce
}

\author{
Cahit Guven, Claudia Senik, and Holger Stichnoth
}

Download this ZEW Discussion Paper from our ftp server:

ftp://ftp.zew.de/pub/zew-docs/dp/dp10007.pdf

Die Discussion Papers dienen einer möglichst schnellen Verbreitung von neueren Forschungsarbeiten des ZEW. Die Beiträge liegen in alleiniger Verantwortung der Autoren und stellen nicht notwendigerweise die Meinung des ZEW dar.

Discussion Papers are intended to make results of ZEW research promptly available to other economists in order to encourage discussion and suggestions for revisions. The authors are solely responsible for the contents which do not necessarily represent the opinion of the ZEW. 


\section{Non-technical summary}

This paper asks whether the gap in subjective happiness between spouses matters per se for a couple's risk of separation. We use three panel databases to explore this question. Controlling for the level of life satisfaction of spouses, we find that a higher satisfaction gap, even in the first year of marriage, increases the probability of a separation. We show that this basic relationship between the gap in satisfaction and the probability of separation is robust to a number of different specifications. Moreover, the relationship holds in all three countries that we study: Germany, the UK, and Australia.

Our interpretation is that this higher separation probability results from comparisons of well-being between spouses and from an aversion to an unequal distribution of wellbeing. While a growing number of studies has already underlined that comparisons affect individual well-being, the advantage of the present article is to focus on a plausible and important reference group, namely one's own spouse. Another contribution of the article is to show that subjective variables (here, the gap in life satisfaction) matter for objectively measured outcomes such as a couple's separation. Finally, we believe that our result is interesting for the theoretical literature on the economics of the household, which has so far neglected the consequences that an unequal distribution of well-being may have.

We also explore the hypothesis that it is assortative mating with respect to the baseline level of happiness that affects the risk of separation. We find that it is not only this baseline level, but also the current level of happiness that matters. First, our results hold in fixed-effects estimates that take away the effect of the initial quality of the match between spouses: fixed-effects estimates suggest that a widening of the happiness gap over time raises the risk of separation. Second, we uncover an asymmetry in the effect of happiness gaps: couples are more likely to break up when the difference in life satisfaction is unfavourable to the wife. The information available in the Australian survey reveals that divorces are indeed predominantly initiated by women, and importantly, by women who are unhappier than their husband. Hence, happiness gaps seem to matter to spouses, not only because they reflect a mismatch in terms of baseline happiness, but because they matter as such. 


\section{Das Wichtigste in Kürze (German summary)}

Der Beitrag untersucht, inwieweit Unterschiede in der Lebenszufriedenheit zwischen Partnern die Trennungswahrscheinlichkeit von Paaren beeinflussen. Dazu werden Paneldaten aus drei Ländern analysiert. Zentrales Ergebnis der Studie ist, dass, selbst nach der statistischen Berücksichtigung des Niveaus der Zufriedenheit und anderer relevanter Einflussgrößen, die Trennungswahrscheinlichkeit umso höher ist, je stärker sich die Partner in ihrer Lebenszufriedenheit unterscheiden. Dieser grundlegende Zusammenhang zwischen den Unterschieden in der Lebenszufriedenheit und dem Trennungsrisiko erweist sich als robust und lässt sich in allen drei untersuchten Ländern (Deutschland, Vereinigtes Königreich und Australien) nachweisen.

Wir werten dieses Ergebnis als Beleg dafür, dass innerhalb des Paares Vergleiche der Lebenszufriedenheit stattfinden, und dass es eine Abneigung gegen eine ungleiche Verteilung der Zufriedenheit gibt. Der Einfluss von Einkommens- oder Statusvergleichen auf die individuelle Zufriedenheit wurde bereits in einer Reihe jüngerer Studien herausgearbeitet; der spezielle Beitrag der vorliegenden Studie liegt in ihrem Fokus auf einer plausiblen und bedeutsamen Referenzgruppe, nämlich dem eigenen Lebenspartner oder der Lebenspartnerin. Ein weiterer Beitrag besteht darin, die Bedeutung subjektiver Variablen (hier: von Unterschieden in der Lebenszufriedenheit) für objektiv messbare Ereignisse wie etwa die Trennung eines Paares aufzuzeigen. Auch für die theoretische Literatur in der Familienökonomie sind die Ergebnisse von Interesse, denn bisher wurden die Folgen einer Ungleichverteilung der Lebenszufriedenheit für den Haushalt in den theoretischen Modellen kaum berücksichtigt.

Die Untersuchung geht auch der Frage nach, ob die erhöhte Trennungswahrscheinlichkeit allein Ausdruck eines schlechten Matches hinsichtlich des vor allem in der psychologischen Literatur diskutieren Baseline-Niveaus der Lebenszufriedenheit ist. (Das Baseline-Niveau ist das langfristig erreichte Niveau der Zufriedenheit.) Wir finden jedoch Anzeichen dafür, dass auch der aktuelle und nicht nur der Baseline-Wert der Zufriedenheitsdifferenz eine Rolle spielt. Dies wird in Schätzungen deutlich, die über die Zeit konstante Wirkungen eines schlechten Matches kontrollieren. Es ist demnach nicht nur das Niveau der Differenz der Lebenszufriedenheit, sondern auch die Veränderung in der Differenz, für die sich ein Zusammenhang mit dem Trennungsrisiko nachweisen lässt. Ferner zeigen die Schätzungen, dass die Unterschiede in der Lebenszufriedenheit asymmetrisch wirken: Das Trennungsrisiko ist dann besonders hoch, wenn die Frau unzufriedener ist als der Mann. Die Daten für Australien zeigen, dass in der Tat überwiegend Frauen die Scheidung einreichen, und dass diese Frauen tendenziell unzufriedener sind als ihre Noch-Ehemänner. 


\title{
You Can't Be Happier than Your Wife: Happiness Gaps and Divorce
}

\author{
Cahit Guven \\ Deakin University \\ Claudia Senik* \\ Paris School of Economics, University Paris-Sorbonne, \\ IZA Bonn \\ Holger Stichnoth \\ ZEW Centre for European Economic Research, Mannheim \\ Paris School of Economics
}

January 19, 2010

\footnotetext{
${ }^{*}$ Corresponding author. Paris School of Economics (PSE), 48 bd Jourdan, 75014 Paris, France. Email: senik@pse.ens.fr. We thank Pierre-André Chiappori, Andrew Clark, Richard Easterlin, Raquel Fernandez, Andrew Oswald, Justin Wolfers and Katia Zhuravskaya for useful suggestions, as well as participants in the 6th IZA Price Conference in Washington, October 2009, the University of New South Wales seminar in Sydney, the Mental Health and Well-Being Workshop at Deakin, and the Massey University seminar (Palmerston North, New Zealand). We are grateful to CEPREMAP for financial support. All errors are ours.
} 


\begin{abstract}
This paper asks whether the gap in subjective happiness between spouses matters per se, i.e. whether it predicts divorce. We use three panel databases to explore this question. Controlling for the level of life satisfaction of spouses, we find that a higher satisfaction gap, even in the first year of marriage, increases the likelihood of a future separation. We interpret this as the effect of comparisons of well-being between spouses, i.e. aversion to unequal sharing of well-being inside couples. To our knowledge, this effect has never been taken into account by existing economic models of the household. The relation between happiness gaps and divorce may be due to the fact that couples which are unable to transfer utility are more at risk than others. It may also be the case that assortative mating in terms of happiness baseline-level reduces the risk of separation. However, we show that assortative mating is not the end of the story. First, our results hold in fixed-effects estimates that take away the effect of the initial quality of the match between spouses: fixedeffects estimates suggest that a widening of the happiness gap over time raises the risk of separation. Second, we uncover an asymmetry in the effect of happiness gaps: couples are more likely to break-up when the difference in life satisfaction is unfavourable to the wife. The information available in the Australian survey reveals that divorces are indeed predominantly initiated by women, and importantly, by women who are unhappier than their husband. Hence, happiness gaps seem to matter to spouses, not only because they reflect a mismatch in terms of baseline happiness, but because they matter as such.
\end{abstract}

Keywords: divorce, happiness, comparisons, panel, households, marriage JEL codes: J12, D13, D63, D64, H31, I31, Z13 


\section{Introduction}

Are people averse to welfare inequality? Are they making happiness comparisons? Is this taking place even within couples? Based on three different panel datasets, this paper suggests that this is indeed the case. Controlling for the level of well-being ${ }^{1}$ of spouses, as well as their income, age, number of children and other characteristics that have been found to associated with marriage stability, we find that a higher happiness gap between spouses increases the risk of divorce. We take this as a piece of evidence that people care for the distribution of well-being per se. This issue is the main motivation of the paper. Income comparisons, status effects, as well as aversion to income inequality in general, have been widely documented, especially in the realm of the labor market, but also in society as a whole (see Clark et al. 2008; Senik 2009). Yet, the ultimate interest of researchers, policy-makers and human beings in general lies in well-being, not in income per se. The usual focus on income is because income, as opposed to well-being, is an observable proxy and a metric of well-being, not only for researchers, but also in the daily experience of individuals, workers and citizens. However, in small organizations, in which people are involved into frequent, repeated and long term relationships, well-being could to a certain degree be observable. Couples are obviously an extreme case of this type of situations and it has actually been shown that spouses are able to predict each other's declared happiness (Sandvik et al. 1993). Actually, couples represent one of the rare real life groups (as opposed to experimental settings) in which researchers can be quite certain about the direction of comparisons that potentially occur between agents.

The second motivation of the paper is to contribute to the literature on marriage, divorce, and interactions inside couples. To our knowledge, the hypothesis that there may exist a preference for more equal sharing of utility among spouses has never been explored. Although marriage and divorce may appear as ultimately private matters, they actually bear important implications in terms of economic outcomes. For instance, as suggested by Becker et al. (1977), the perspective of separation reduces the incentives of spouses to invest in marriage specific assets such as the number and human capital of children. Divorce is also related, both as a cause and a consequence, to the participation of women in the labor market. Marriage and divorce and the regulations that relate to them thus have a potential influence on these important aspects of economic life.

\footnotetext{
${ }^{1}$ Here we use the terms well-being, life satisfaction and happiness indifferently, and we assume that these three self-declared mental states are approximations of experienced utility (as opposed to decisionutility, which is unobservable, see Kahneman et al. 1997). De facto, these measures are highly correlated. For instance, the correlation between self-declared life satisfaction and self-declared happiness, both measured on a 1-10 ladder, is 0.7 in the European Social Survey (waves 2002, 2004, 2006).
} 
The third objective of the paper has to do with the reliability of subjective variables. Showing that self-declared happiness actually has a predictive power on decisions and actions can strengthen the idea that it reflects more than the noise produced by mood, social desirability biases, framework effects, question ordering and other unessential phenomena. In the same spirit, Freeman (1978), Clark (2001), and Kristensen and Westergard-Nielsen (2006) have shown that job satisfaction is a strong predictor of job quits, even when controlling for wages, hours of work and other standard individual and job variables.

We use three panel databases that contain a life satisfaction question labelled in a very similar way. The German Socio-Economic Panel (GSOEP, 1984-2007), the British Household Panel Survey (BHPS, 1996-2007) and the Household, Income and Labour Dynamics in Australia Survey (HILDA, 2001-2007). The two former have been widely used by the scientific community, especially in the field of happiness economics.

We find that a happiness gap between spouses in any given year is positively associated with the likelihood that a separation occurs in the following year. In order to mitigate concerns about reverse causation, we show that even a happiness gap in the first year of marriage (for couples who were surveyed during their first year of marriage) increases the risk of a separation in any of the subsequent years in which individuals are observed. We interpret this finding as resulting from an aversion to unequal sharing of well-being inside couples. One explanation may be that couples that are unable to transfer utility are more at risk than others. It may also be the case that assortative mating in terms of happiness baseline-level reduces the risk of divorce. However, we show that assortative mating is not the end of the story. First, our results hold in fixed-effects estimates that take away the effect of the initial quality of the match between spouses: fixed-effects estimates suggest that a widening of the happiness gap through time raises the risk of separation. We also find that, after controlling for the lagged values of the happiness gap, the coefficient on the current happiness gap is still statistically significant, which we interpret as a sign that the effect goes beyond assortative mating.

Finally, we uncover an asymmetry in the effect of happiness gaps: the latter increase the risk of separation when the wife is less happy than her husband, but the reverse is not true. The information available in the Australian survey reveals that divorces are indeed predominantly initiated by women. It also shows that women who report to be the initiator for divorce were actually less happy than their husbands, whereas this is not the case when the separation was initiated by the husband or by both spouses.

Hence, happiness gaps seem to matter to spouses, not only because they reflect a mismatch in terms of baseline happiness, but because they matter as such. 


\section{Happiness gaps and divorce in the economic liter- ature}

This paper belongs to the economic analysis of marriage and divorce. This literature has focused on the reasons for marriage ${ }^{2}$, on the cause of marriage instability, on the behavior of spouses in terms of demand for goods and supply of labor, on the efficiency of the equilibrium in the case of cooperative and non-cooperative bargaining. However, to our knowledge, the literature has barely addressed the issue of the difference in spouses' utility or well-being as such.

In altruistic household models à la Becker (1974), the head of the household cares for the welfare of each member, but not for the equality of welfare among members as such. In collective models à la Chiappori $(1988,1992)$, spouses try to reach the highest collective utility frontier, and then choose a point on the frontier to regulate the division. The sharing rule depends on their respective preferences and bargaining power ("distribution factors"), which depend inter alia on spouses' outside wage, marriage and divorce legislation, child custody rules, or the sex ratio on the relevant (re-)marriage market. But the sharing rule does not include a constraint on the degree of equality of outcomes. It is true that: "In general, the higher the degree of caring, the narrower will be the range of conflict. That is, both partners will agree to delete extremely unequal distributions from the family's choice set" (Weiss 1997, 93). But this does not mean that caring spouses will necessarily equalize their well-being. In the case of non-cooperative models, where members are represented as being linked by externalities, but acting non-cooperatively, each person determines the variable under her control, taking the decision of her spouse as given: the outcome can thus clearly be distributed very unequally across spouses, depending on their relative threat points. Finally, couple dissolution occurs endogenously when the value of marriage is less than the value of divorce. In cooperative models, utility transfers take place until the aggregate utility of the marriage falls behind the total utility of divorce. Again, utility gaps do not play any role in this decision. This very brief discussion shows that the economic models of marriage do not contain any prediction concerning the relation between utility gaps between spouses and the risk of divorce.

However, as underlined by Becker et al. $(1977,1144)$, in the case of cooperative bargaining: "The conclusion that a couple dissolves their marriage if, and only if, their combined

\footnotetext{
${ }^{2}$ Marriage is considered as a "partnership for joint production and joint consumption", such as "producing and rearing children" (Weiss 1997). Other justifications for marriage include the existence of couple-specific production technology or complementarities/substitutability between goods. Marriage as a long term arrangement is also grounded on the benefits yielded by increasing returns to scale, the division of labor, risk pooling and improved coordination between spouses Weiss (1997).
} 
wealth when dissolved exceeds their combined married-wealth, is a direct extension of the conclusion that single persons marry if, and only if, their combined married-wealth exceeds their combined single-wealth. Both conclusions assume that the division of wealth between spouses is flexible". By contrast, in the case where utility is not transferable, unilateral decision to divorce may happen even when they are not Pareto-improving. Hence, the non-transferability of utility makes divorce more likely. As a corollary, marriages with a very unequal distribution of welfare may be more unstable, because of the impossibility to implement transfers of utility that could be Pareto-improving (if preferences are "caring"). In the case of non-transferable utility, couples in which spouses are similar can be expected to be more stable, as their similar features reduce the scope of conflicts. Hence, when utility is not transferable, positive assortative mating is likely to be favorable to the stability of marriage.

All in all, in the economic models of the household, once actions and sharing of utility are realized (depending on the preferences and threat-points of each member), there is no reason to expect that the remaining happiness gap should affect the likelihood of divorce. In terms of empirical investigation, controlling for the variables that capture the gains to marriage and the value of exiting the marriage for each spouse, and the total happiness of the couple, there should thus be no statistical association between happiness gaps and divorce. This paper tests this prediction. It finds that on the contrary, ceteris paribus, happiness gaps are robustly associated with a higher likelihood of a future separation. This result suggests that couples who are not willing or not able to realize equalizing utility transfers are less viable than otherwise. Our interpretation is that this reflects a concern for the distribution of welfare per se.

This paper naturally belongs to the subset of literature dedicated to marriage, divorce and self-declared happiness, as measured in household surveys. A series of papers in economics and psychology have shown evidence that, as compared to remaining single, marriage has a positive impact on mental health (Gove et al. 1983), on physical health (Wilson and Oswald 2005), on life satisfaction (Stutzer and Frey 2006; Zimmermann and Easterlin 2006) and on life expectancy (Gardner and Oswald 2002; Hu and Goldman 1990). Stutzer and Frey (2006) have shown that the higher happiness of married people is partly due to a selection effect (those to-be-married in the future are already happier than those to-remain-single, even before they marry), but not entirely. Concerning divorce, using the BHPS, Gardner and Oswald (2005) have shown that "divorcing couples become happier by breaking up". Hu and Goldman (1990), in a longitudinal survey, estimated that divorced males have the highest ratios of mortality, relative to the married population, in Asian countries, North America and Europe. However, this could stem from a selection effect, as Stutzer and Frey (2006) found that the lower happiness of divorced people was 
already observable during their marriage.

A few papers of the same literature have tried to address the idea of altruism and intrahousehold externalities of welfare. Powdthavee (2004) for instance has shown evidence of positive spillovers of subjective well-being among spouses, using the British Household Panel Survey. In a recent paper (Powdthavee 2009), he also shows that a negative correlation of spouses' subjective well-being is associated with a higher likelihood of divorce. Schimmack and Lucas (2007), using the German Socio-Economic Panel, also find some evidence of spousal similarity in life satisfactions. Bruhin and Winkelmann (2009) provide evidence that parents' self-declared happiness is positively correlated with their children's happiness; more "altruistic" parents actually make higher financial transfer payments to their children.

Finally, this paper belongs to the literature dedicated to the effects of income distribution and income comparisons on subjective well-being (see the surveys by Alesina and Giuliano 2007; Clark et al. 2008; Senik 2009). The difficulty in identifying the direction, intensity and welfare effects of income comparisons has been addressed by an important literature in the last decade. Empirical studies have predominantly documented the negative effect of income comparisons, except in the case of signal effects whereby people compare to others in order to acquire information about their own future prospects. As already noticed, couples represent one of the rare real life groups (as opposed to experimental settings) in which researchers can be quite certain about the direction of comparisons that potentially occur between agents. With respect to this literature, the contribution of this paper is to show evidence of happiness comparisons in the realm of within-household interactions.

The next section presents the data. Section 4 presents the empirical specification. Section 5 discusses the results and Section 6 concludes.

\section{$3 \quad$ Data}

We use three large panel surveys, the German Socio-Economic Panel (GSOEP), the British Household Panel Survey (BHPS) and the Household, Income and Labour Dynamics in Australia (HILDA), which include subjective happiness questions and contain information about all adult members within households. Descriptive statistics of the datasets are presented in the Appendix.

Admittedly, the focus of this paper is not on the comparison between Germany, the United-Kingdom and Australia. Rather, our motivation is that the BHPS and the 
GSOEP are among the main panel datasets that have been used in the happiness literature, so that results obtained with both sources will have more generality. We complement these by a more recent data set (HILDA) that contains very useful subjective variables. Conducting the same analysis separately on three data sets is a way to include a self-contained "replication check" on the validity of the results. Using several datasets also allows relating complementary pieces of information. For instance, the GSOEP has information on expected life satisfaction, whereas HILDA has, among other things, information about who initiated the divorce.

\subsection{The GSOEP}

The GSOEP ${ }^{3}$ is a wide-ranging representative longitudinal study of private households, which has been conducted annually since 1984. It includes information on objective living conditions and many subjective attitudes. Self-declared happiness ("How satisfied are you with your life, all things considered?") is a categorical variable that takes on values 0-10 (where 0 is "totally unhappy" and 10 is "totally happy") and is available for every year in the survey. GSOEP includes a separate spell dataset for marital status, indicating the beginning and ending date of each marriage spell.

Our regression sample covers the years 1984-2007, and includes 224758 legally married person-years and 28576 cohabitating person-years. From 1984 to 2007, we have 4074 separations. 2460 separations are from legally married people and 1614 are from de facto relationships. In average, couples are observed for an average duration of 21.2 years (21.9 for legally married people and 5.3 for de facto relationships). We also observe 3253 new marriages. We restrict the sample to individuals aged 18-65, and we exclude transitions into widowhood. Our regression sample thus includes 253334 observations with a valid partner number, i.e. 58374 individuals. The probability of separation from one's partner, conditional on having a partner in the previous period, is 2.02 .

\subsection{The BHPS}

The BHPS ${ }^{4}$ is a longitudinal annual household survey that began in 1991 . The wording of the life satisfaction question that we are using is "How dissatisfied or satisfied are you with your life overall?" The answers are measured on a scale from 1 (not satisfied at all) to 7 (completely satisfied). This question about life satisfaction has been asked in

\footnotetext{
${ }^{3}$ For further information on the GSOEP: http://panel.gsoep.de/soepinfo2008/

${ }^{4}$ Detailed information about the BHPS can be found at http://www.iser.essex.ac.uk/survey/ bhps
} 
all waves since 1996, with the exception of 2001. Our regression sample contains only people who live with a partner for at least one year during the period of observation. We also restrict the sample to individuals aged $18-65$, and we exclude transitions into widowhood. These restrictions leave us with 90727 person-year observations with a valid partner identifier. These observations come from 15226 individuals. For 1743 observations (that is, about $2.3 \%$ of the sample), we observe a break-up. In most of the estimations, we further restrict our sample to married couples. In this case, the number of person-year observations is 72619 , for 11814 individuals. As is to be expected, the share of separations is lower for married couples, at about $1.3 \%$.

In the BHPS, the (uncensored) length of marriage is only available for a subset of the individuals, and only for first marriages. This average length is about 21.1 years. The average number of years in which an individual (married or not) is observed with the same partner in our sample (conditional on being together in period t) is about 4.1 years. This is of course a left-censored measure of the duration of the couple.

\subsection{HILDA}

HILDA is an Australian nationally representative household-based panel study, run annually since 2001 in order to collect information on economic and subjective well-being, labor market dynamics and family dynamics in Australia. ${ }^{5}$ Interviews are conducted annually with all adult members of each selected household. Respondents declare their level of life satisfaction: "All things considered, how satisfied are you with your life? Pick a number between 0 and 10 to indicate how satisfied you are (0: Totally dissatisfied, 5: Neither satisfied nor dissatisfied, 10: Totally satisfied)". The data has very detailed information on relationships and life events that occur in each year. This paper uses the first seven waves of the HILDA survey (2001 to 2007). We consider all individuals who have been married or living with a partner at least once during the survey and whose partner is also identified. Our regression sample contains 25716 individuals for a total of 90548 person-year observations. From 2001 to 2007, we observe 2865 separations and 1813 marriages. In the survey, couples are observed for an average duration of 19.5 years (22.7 for legally married people and 4.8 for de facto relationships).

For each survey, we construct two datasets: the sample of women and the sample of men, which contain all women (resp. men) who have been married or living with a partner at some point during the survey. Each woman (resp. man) is matched with her spouse or partner. Each sample contains the information on each women (resp. man) and her

\footnotetext{
${ }^{5}$ See http://www.melbourneinstitute.com/hilda/
} 
spouse or partner.

In the three databases, women appear to be slightly happier than men. ${ }^{6}$ The absolute value of the happiness gap between spouses is represented in figures 1, 2 and 3 in the Appendix. In general, in about one third of couples, both spouses declare exactly the same happiness level. A difference of one step is observed in over another third of couples. Hence, the situation in which spouses equalize their levels of happiness is indeed predominant.

\section{Empirical specification}

Following the existing empirical literature (see Becker et al. 1977; Bumpass and Sweet 1972; Smock et al. 1999; Weiss and Willis 1997), we model the probability of a separation depending on the value of being in marriage versus out-of-marriage (household income, education of spouses, children, duration of marriage) and of the potential threat points of each spouse (individual income, education, age and age difference between spouses, etc.). We are interested in testing the null hypothesis that the coefficient on the happiness gap is not significant. Our basic specification is the following:

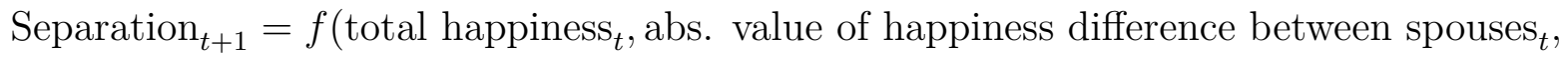
age $_{t}$, age difference, $\log ($ household income $)$, number of children $\left.t\right)$

where $^{\text {Separation }} t_{t+1}$ is the probability that a couple observed in year $t$ is dissolved in year $t+1$, and total happiness ${ }_{t}$ is the sum of the self-declared happiness of the spouses in year $t$.

Because of collinearity, it is not possible to include husband's happiness, wife's happiness and the happiness difference between spouses among the explanatory variables. We therefore need to recourse to a nonlinear specification of the happiness gap between spouses. Our main specification consists in including the absolute value of the happiness gap between a respondent and her spouse, together with the total happiness gap. As an alternative specification, we also consider dummy variables that take value one if the self-declared happiness of the wife is greater (respectively lesser and equal) than that of

\footnotetext{
${ }^{6}$ In GSOEP, for the 112811 observations on married women, the difference is 0.035 (significant at 1\%) and for the 14691 observations on cohabiting women, the difference is 0.039 (significant at $5 \%$ ). In the BHPS, for the 32735 observations on married women, the difference is 0.045 (significant at $1 \%$ ) and for the 6678 observations on cohabiting women, the difference is 0.018 (not significant). Finally, in HILDA, for the 23432 observations on married women, the difference is 0.118 (significant at $1 \%$ ) and for the 5368 observations on cohabiting women, the difference is 0.074 (significant at $1 \%$ ).
} 
the husband. In robustness analysis, we also use the ratio of the happiness level of the happier spouse to the unhappier one, and of the wife to the husband. We estimate these relations on the pooled data, using alternatively a probit specification and a fixed-effect logit specification. In the probit models, we cluster standard errors by individual, in order to correct for the autocorrelation of observations that pertain to the same individual.

Because we model the probability to divorce, a possibility could be to use a duration model. However, Sueyoshi (1995) has shown that a much simpler logit or probit model with period specific variables yields similar results. Kraft and Neimann (2009) use a complementary log-log model with a marriage duration specific dummy variables, which is perfectly equivalent to a discrete-time proportional hazard model, but is better suited for the analysis of rare events like divorce. We check that our results are maintained with this specification.

In addition to this basic specific specification, in the robustness analysis, we control for other determinants of divorce which have been uncovered by the empirical literature, such as, for both spouses: religion, objective and subjective health, BMI, height, duration of marriage, country of origin, labor market status, work experience, years of schooling, number of working hours, months of previous unemployment, house ownership, number of previous legal marriages and cohabitations, management of household budget, share of household work, the fact of having had divorced parents, etc. (see for instance Weiss and Willis 1997). We also control for year fixed effects in the probit estimates.

Of course, this exercise is based on the assumption that spouses compare their level of happiness, i.e. that they are able to observe the level of happiness of their spouse. It has indeed been shown (Sandvik et al. 1993) that the level of happiness declared by an individual is correlated with the level of happiness that her spouse perceives her to experience. To be safe, we run fixed-effect estimates that eliminate any anchoring effect or misperception of happiness that could characterize a couple in an invariant way.

We present the results based on the sample of women. The same results are obtained on the sample of men. Due to space constraints, we do not reproduce the latter in the text, but we keep them available to any interested reader. 


\section{Results}

\subsection{Happiness gaps increase the likelihood of separations}

Tables 1, 2 and 3 present estimation results for our basic specification. Controlling for the total level of happiness of a couple (as well as age, age difference between spouses, number of children and log real household income), an increase in the happiness gap of one unit raises the probability of separation by $0.24 \%$ in Germany (GSOEP), $0.3 \%$ in Australia (HILDA) and $0.1 \%$ in the United-Kingdom (BHPS). Given that the average risk of separation in the samples is about $1.8 \%$, this represents a non negligible share of the average risk of break-ups.

Table 1: GSOEP. Probit estimate of the probability to break-up next year. Female sample.

\begin{tabular}{lrr}
\hline & Marg. eff. & $\mathbf{t}$ \\
\hline Absolute value of happiness difference & $\mathbf{0 . 0 0 2 3 6 9}$ & $\mathbf{8 . 3}$ \\
Total happiness & -0.002223 & 17.0 \\
Age & -0.002223 & 6.1 \\
Own age minus spouse age & -0.000103 & 1.0 \\
Number of children & -0.003781 & 7.5 \\
Log real monthly household income & -0.004058 & 4.6 \\
Pseudo R-squared & 0.0332 & \\
Number of observations & 100644 & \\
\hline
\end{tabular}

Note: Whole sample (married and cohabiting). Standard errors clustered at individual level

Table 2: HILDA. Probit estimate of the probability to break-up next year. Female sample.

\begin{tabular}{lrr}
\hline & Marg. eff. & $\mathbf{t}$ \\
\hline Absolute value of happiness difference & $\mathbf{0 . 0 0 3 0 2 0}$ & $\mathbf{4 . 1}$ \\
Total happiness & -0.003183 & 7.7 \\
Age & -0.000990 & 12.0 \\
Own age minus spouse age & 0.000922 & 3.7 \\
Number of children & 0.001416 & 1.9 \\
Log real monthly household income & -0.026942 & 0.9 \\
Pseudo R squared & 0.0845 & \\
Number of observations & 19394 \\
\hline
\end{tabular}

Note: Whole sample (married and cohabiting). Standard errors clustered at individual level

Running the estimates separately on the sub-sample of legally married people versus cohabitating couples, we find that the effect of the happiness gap is typically several 
Table 3: BHPS. Probit estimate of the probability to break-up next year. Female sample.

\begin{tabular}{lrr}
\hline & Marg. eff. & $\mathbf{t}$ \\
\hline Absolute value of happiness difference & $\mathbf{. 0 0 1 0 1 9}$ & $\mathbf{1 . 9}$ \\
Total happiness & -.003926 & -12.5 \\
Age & -.001179 & -20.8 \\
Own age minus spouse age & .000341 & 2.5 \\
Number of children (aged $<16)$ & -.0005622 & -1.0 \\
Log real monthly household income & -.003585 & -4.0 \\
Pseudo R squared & 0.11 & \\
Number of observations & 30897 & \\
\hline
\end{tabular}

Note: Whole sample (married and cohabiting). Standard errors clustered at individual level

times higher for cohabitating couples than it is for legally married couples. For instance, in Germany, an increase of 1 in the happiness gap raises the probability of separation by $0.16 \%$ for legally married couples, versus $0.5 \%$ for cohabitating couples. In Australia, an increase of 1 percent in the happiness gap raises the probability of a break-up by $0.2 \%$ for legally married couples, versus $0.9 \%$ for cohabitating Accordingly, when we introduced a dummy variable standing for legally married (versus de facto) couples, the coefficient associated to this dummy was always statistically significantly negative (with $1 \%$ confidence level) and varied from $-2 \%$ (GSOEP and BHPS) to $-5 \%$ (HILDA). In the sequel, in order to be conservative, we display the results obtained with the sub-sample of legally married couples, and we mention the size of the effect for the rest of the sample in the text.

In order to understand which couples are most concerned by this effect, we interacted the absolute value of the happiness difference with a large number of variables. (In these models, we also included the interacted variables as regressors to capture not only the interaction effects, but also the main effects). It turned out that few variables significantly modify the effect of the happiness gaps. The statistical association between happiness gaps and the risk of divorce was particularly strong for higher levels of female income and for couples where the housework load is supported predominantly by women (GSOEP). It was weaker for women who declared that they attach a high importance to family (GSOEP, HILDA), to a good partnership (BHPS) or to religion (HILDA), and for couples with a longer marriage duration (HILDA, BHPS).

The effects of the other controls included in our main specification are consistent with the existing literature: the probability of divorce decreases with the log of total real 
household income and with the age of spouses, but increases with the age difference (wife - husband). The association between the number of children and marriage stability was most often negative but not stable.

For robustness, we added a series of additional controls to our main specification. The main result (i.e. the association between the happiness gap and the probability of divorce) proved robust to the inclusion of these controls. Because of space constraints, we cannot report all the results in the entire tables; we simply cite the controls that appeared to be statistically significantly correlated with the probability of divorce. The most remarkable (but classical) result is that the risk of divorce increases with the wife's individual income but falls with the husband's individual income. Other factors that increase the risk of divorce include self-employment of the husband, and having divorced parents. Controls that are negatively associated with the risk of divorce are situations in which the wife is retired, housewife or full-time student (controlling for age), the age at marriage (which is usually taken to capture the length of the search, hence the quality of the marriage), spouses being born in the same country, sharing the same religion (especially if catholic) owning one's house (GSOEP, HILDA), declaring "a fair sharing of housework" (see also Stauder 2005; Kraft and Neimann 2009), couples in which finance are shared or maintained separately rather than managed by one spouse only (BHPS), and, of course, own and spouse's individual happiness and subjective mental health. The effect of education on marriage stability is not stable, conformingly to the literature, which posits an a priori ambiguous effect. ${ }^{7}$

We also ran various other robustness tests. In terms of specification, we checked that the results show in Tables 1, 2 and 3 were left essentially unchanged in a complementary $\log -\log$ specification, as well as in a rare events logit specification. We also checked that the results were essentially unchanged when the German sample (GSOEP) was restricted to West Germans. As a measure of the happiness gap, we replaced the absolute value of the happiness difference with the ratio of wife/husband's happiness, or of the happier to the unhappier spouse. We also replicated all our results using the post-estimation residual happiness (including the usual controls as defined in equation (1)) instead of the happiness level (see Powdthavee 2009). The results were essentially unaltered. Because of space constraints, we do not display all these robustness tests.

\footnotetext{
${ }^{7}$ Higher education makes an individual financially less dependent on her spouse, but on the other hand, it increases the non monetary gain from marriage due to the valuable characteristics of this person and it also reduces the chance that her expectations concerning marriage were false (Kraft and Neimann 2009).
} 


\subsection{Ruling out reverse causality and other alternative explana- tions}

We interpret the effect of happiness gaps on divorce as expressing a concern for relative happiness. However, we need to rule out alternative interpretations, such as the reverse causality running from the expectation of divorce in the near future to the happiness gap. Infidelity of one spouse is likely to create such a situation, especially if the infidel spouse is planning to dissolve her marriage in order to form another couple with her new partner (South and Lloyd 1995). More generally, reverse causality could stem from a situation in which the marriage is failing and the perspective of divorce makes one of the spouses more unhappy than the other.

It could also be the case that an unexpected event affects both spouses differently and destabilizes the couple by creating a wedge between the expected value of marriage and its realization (Becker et al. 1977). Examples of this include shocks to the expected earning capacity of a spouse (Weiss and Willis 1997), job losses or health shocks (Charles and Stephens Jr. 2004).

We try to rule out these mechanisms using different methods. First, we control for one to five years lagged values of the happiness gap. This is useful if the impact of a shock is likely to be felt in the couple of years after it occurs. As shown by table 13, we do observe a significant impact of lagged happiness gaps on the probability to divorce in $(t+1)$.

However, the effect of shocks, or infidelity, may be more persistent. In order to go as far as possible in trying to overcome this problem, we consider the sub-sample of couples who are already under observation in the survey in the first year of their marriage. We then look at the effect of the absolute value of the happiness gap in the first year of marriage on the probability to ever divorce in subsequent years, during the period of observation. Tables 14, 15 and 16 show that an initial happiness gap of 1 increases the probability that a separation is observed during the observation period by 2.3 percentage points in Germany and Australia, and by 4.3 percentage points in the United Kingdom.

We thus observe a statistically significant effect of happiness gaps in the first year of marriage, hence (hopefully) before the occurrence of most shocks. We also checked that our main result holds when controlling for shocks to the income and health status of each spouse. Introducing such controls did not change the order of magnitude of the coefficient on the happiness gap. In the BHPS, disability, unemployment or self-declared health status of either spouse did not have a statistically significant impact on the probability to divorce. In the GSOEP, we used company closures and unexpected disability shocks, which are likely to be exogenous events. We found that these were not statistically 
associated with the probability to divorce in later years. Concerning the Australian survey, we used a series of reported life events, such as serious personal injury/illness, serious injury/illness to a family member, death of child, death of close relative, death of a close friend, being victim of physical violence, victim of property crime, detained in jail, fired, retired, major improvement in finances, major worsening in finances. All these additional controls did not change the magnitude of the coefficient on the happiness gap.

Finally, concerning the difference between expectations and realizations, we used a series of questions of the GSOEP, labelled in the following way: "1. In conclusion, we would like to ask you about your satisfaction with your life in general. Please answer according to the following scale: 0 means 'completely dissatisfied', 10 means 'completely satisfied'. 2. And how do you think you will feel in five years? 3. How happy were you a year ago with your life? 4. And what do you think it will be like in a year's time?" We include the difference between current happiness (question 1) and 5-years-lagged expected future happiness (question 2); we also include the difference between current happiness (question 1) and one-year-lagged expected happiness (question 4). Including these additional controls in the main specification left our main result unchanged.

\subsection{Assortative mating}

The finding that happiness gaps, even those that are already observable in the first year of marriage, are associated with a higher risk of divorce could be interpreted as a sign of assortative mating in terms of happiness baseline-level. The economic theory of marriage predicts a "predominance of positive assortative mating with respect to personal characteristics such as education, height, intelligence, age, property income, physical attractiveness, etc. [...] all traits which are not good substitutes in the production of commodity income, while negative assortative mating would be optimal for substitutes, such as wage earning power" (Becker et al. 1977, 1146). This prediction has been confirmed by several empirical studies (e.g. Lehrer and Chiswick 1993; Contoyannis and Jones 2004; Kalmijn 1994; Kalmijn et al. 2005). As an illustration, Weiss and Willis (1997) find evidence that couples with similar level of schooling are more likely to marry and less likely to divorce. Likewise, similarity in terms of age, region of origin, ethnicity, religion, and social background have been found to be associated with longer durations of marriages (see Frimmel et al. 2009, for a survey), an observation that is confirmed in our surveys (see section 5.1).

Matching could also happen along the dimension of well-being. Some psychologists (Lykken and Tellegen 1996; Headey and Wearing 1992) have suggested that individu- 
als are characterized by a setpoint (or baseline-level) of happiness, considered as a type of personality trait, partly determined by genetics. In this view, individuals can deviate from their baseline-level following shocks, but will eventually return to this level after a process of adaptation. Fujita and Diener (2005) and Schimmack and Lucas (2007) have questioned the relevance of this theory using the GSOEP. They found that individual self-declared happiness fluctuates significantly across time and is less stable than other objective health measures such as weight, body mass index, systolic and diastolic blood pressure and personality traits. Nonetheless, we do find some sign of assortative mating in the three datasets that we use.

First, the happiness levels of spouses are positively correlated. This point is illustrated by figures 1, 2 and 3, and has been established in the literature, in particular by Powdthavee (2004) and Schimmack and Lucas (2007). Second, we followed some authors who have noticed that individuals remain in a certain zone of the happiness scale most of their lives (Davern et al. 2007; Cummins et al. 2008). For instance, people whose declared happiness level is under 5 on a 0-10 ladder rarely bypass that threshold; conversely, people whose declared level is above 7 rarely fall behind this threshold. Accordingly, we divided the samples of couples who are observed in their first year of marriage into three groups, depending on their level of happiness in their first year of marriage. We then tabulated the cross-distribution of spouses' happiness in terms of these groups. In Tables 7,8 and 9 in the Appendix, the frequencies are particularly high in the diagonal. A majority of women appear to be matched with men of the same happiness category. For instance, in the United-Kingdom, $61 \%$ of the highest happiness tier women appeared to be married with men of the same category. $48 \%$ of women of the intermediate happiness group were married with men of the same category. These figures are even higher in Germany and Australia.

A possible interpretation of the joint findings of (i) assortative mating with regards to well-being and (ii) the effect of happiness gaps on divorce, could be that utility (or well-being) is not easily transferable among spouses. The economics of the household usually assumes that utility transfers are possible, and take the form of income transfers, compromise, or spillovers of happiness, i.e. contagion. However, if well-being is not transferable, and if happiness gaps matter per se, it is important to choose a partner whose level of well-being is "naturally" on the same level as one's own, either because it is a natural personality trait as such, or because both spouses have identical preferences, which lead them to chose similar actions and reach similar levels of "primary" happiness (before any redistribution). In this framework, our results can be interpreted as a sign of positive assortative matching and limited transferability of utility. 
However, assortative mating does not totally explain the effect of happiness gaps on divorce. First, we find that, after controlling for the lagged values of the happiness gap, or for the initial happiness gap in the first year of marriage, the coefficient on current happiness gap is still statistically significant in all surveys. ${ }^{8}$ Second, we show that the risk of future divorce is associated not only with the level of the happiness gap but also with its evolution in time. The effect of happiness gaps on divorce holds in fixed-effect logit estimates, which eliminate the effect of the time-invariant quality of the match between spouses. Tables 17 and 18 show that when the happiness gap becomes unfavourable to the wife, this increases the risk of divorce (the results are not statistically significant for the Australian dataset). Hence, the effect of happiness gaps on the risk of divorce cannot be entirely attributed to the initial quality of the marriage.

Finally, in the three datasets, we checked that the happiness gap between former spouses decreases with time after divorce $\left(\chi^{2}\right.$ tests reject the null that the happiness gap is equal before divorce and 2 years, 3 years and 4 years after divorce, at 1\%). However, admittedly, the happiness gap between former spouses always remains statistically significantly higher than that of couples who remain married (by a magnitude of $15 \%$ to $30 \%$ depending on the dataset; $\chi^{2}$ tests reject the null that the happiness gap is equal for divorced and married couples at $1 \%$ ).

\subsection{Asymmetry}

An important observation, which suggests that assortative matching does not entirely explain our findings, is that the effect of happiness gaps is asymmetric. Happiness gaps are associated with a higher probability of a future divorce only when they are unfavourable to women, but not to men. Tables 19, 20 and 21 show that the situation in which the wife is unhappier than her husband is associated with a higher risk of divorce in the following year: by $0.5 \%$ in Germany, $0.4 \%$ in Australia, and $0.3 \%$ in Great-Britain. Concerning cohabitating couples, the risk is ten times higher. This asymmetry holds in the fixed effects estimates, as already shown by Tables 17 and 18. The effect is again ten times higher for cohabitating couples.

This naturally leads to the question whether divorce is actually initiated by women when they are unhappier than their husband. In the 2005, 2006 and 2007 waves, the Australian survey contains retrospective information on the person who initiated the separation. The findings are impressive: in the sample of female respondents, $60 \%$ of women report that they were responsible for the decision to separate. Only $16 \%$ of women attribute the

\footnotetext{
${ }^{8}$ Note that the correlation between current happiness gaps and lagged values is constantly inferior to 0.3 .
} 
responsibility to their husband and $24 \%$ declare that the separation was initiated by both spouses. Surprisingly, in the sample of husband respondents, $36 \%$ report that the divorce was initiated by their wife, $27 \%$ by themselves and $37 \%$ that it was a joint decision. Hence, it does seem that divorces are predominantly initiated by women, although the exact proportion is subject to doubt. In the case of Germany, a study of the Ministry of the family, realized in 2003, also shows that about two thirds of divorces are initiated by women (quoted by Kraft and Neimann 2009).

Importantly, the Australian data also reveals that women who report to have initiated divorce were actually less happy than husbands. ${ }^{9}$ By contrast, $\chi^{2}$ tests do not allow rejecting the null hypothesis of equality of satisfaction between spouses when the decision to divorce has been taken by both spouses or by the husband. This is consistent with the idea that some divorces are initiated by women, not only because they are unhappy, but because they are less happy than their husband.

Are women more subject to happiness comparisons; do they attach more importance to the couple as a spillover mechanism; or do they expect more from their marriage than men, as opposed to other domains of life? We are unable to answer these questions at this stage. In years 2000 to 2007, a special module of the GSOEP, dedicated to youth biography, surveyed members of the households aged 16 to 19 years old, i.e. 2805 individuals (each individual surveyed only once). Some of the questions shed some light on our results. The survey shows that a slightly higher proportion of women expect to get married ( $70 \%$ versus $68 \%$ for men) rather than to live with a partner $(50 \%$ versus $53 \%$ ); however, women less often consider that "a partner is necessary to be happy in life" (64\% versus $71 \%$ ). A proportion of $32 \%$ of women (but only $25 \%$ of men) consider that "one can be just as happy without a partner". Women also more often than men declare that "it is all right for a couple with an unhappy marriage to get a divorce, even if there are children", or that "marriage is an outdated institution", and less often agree that "marriage is a lifetime relationship and should never be ended" (all these differences are statistically significant). This suggests that the new generation of German women do not exclude exit (rather than voice or loyalty) as a possible solution in case of marital conflict.

\footnotetext{
${ }^{9}$ Their average level of happiness was 6.89 (0.30) versus $7.7(0.21)$ for their husband, and the difference is significant at the $5 \%$ level ( $\chi^{2}$ test statistic of 0.0104$)$.
} 


\section{Conclusions}

This paper offers new empirical evidence concerning the existence of happiness comparisons between spouses. Conditional on the individual levels of happiness, or on the aggregate level of happiness of the couple, a higher happiness difference between spouses reduces the stability of their marriage.

This result is robust to the inclusion of a series of controls that are classically taken to determine the stability of marriage. We address the risk of reverse causation by showing that the risk of divorce is statistically associated with the happiness gap in the first year of marriage (for those who are surveyed in the first year of their marriage). This finding points to the potential importance of assortative mating. However, the effect of happiness gaps goes beyond assortative mating, as shown by fixed effects estimates that neutralize the invariant quality of the match. Moreover, we uncover an asymmetry in the effect of the happiness gap: the latter is a cause of divorce only in the case when the wife is unhappier than her spouse. Our interpretation of these findings is that there exists a pure preference for equal distributions of well-being in couples, in other words, a comparison of well-being effect between spouses (which is particularly strong for women).

It is possible that couples that are not able to transfer and equalize their happiness levels are more at risk of divorce. In many versions of the popular cooperative models of household bargaining, partners are represented as taking sequentially decisions in order to maximize their joint output (or aggregate welfare) and then distribute it among them. This interpretation rests on the assumption that utility is transferable, i.e. that the initial distribution of well-being across spouses is easily modifiable, exactly as primary income can be modified by income redistribution by the state. However, it may prove difficult to transfer utility between spouses, i.e. to modify the primary distribution of happiness that results from their actions. This could explain why assortative mating in terms of happiness is associated with a higher stability of marriage (because spouses do not need to redistribute utility in this case). This also suggests that when spouses "agree" on too unequal a distribution of welfare, this puts the durability of their marriage at risk. From this point of view, public policy should avoid giving spouses incentives that lead to diverging levels of happiness. Individual income and employment have been shown to be among the main determinants of happiness; policies that affect the division of labour inside households should keep this in mind. 


\section{References}

Alesina, A. and P. Giuliano (2007). The power of the family. Working Paper 13051, NBER.

Becker, G. S. (1974). A theory of marriage: Part II. Journal of Political Economy 82(2), S11-s26.

Becker, G. S., E. M. Landes, and R. T. Michael (1977). An economic analysis of marital instability. Journal of Political Economy 85(6), 1141-1187.

Bruhin, A. and R. Winkelmann (2009). Happiness functions with preference interdependence and heterogeneity: The case of altruism within the family. Journal of Population Economics 22(4), 1063-1080.

Bumpass, L. and J. A. Sweet (1972). Differentials in marital instability: 1970. American Sociological Review 37(6), 754-766.

Charles, K. K. and M. Stephens Jr. (2004). Job displacement, disability, and divorce. Journal of Labor Economics 22(2), 489-522.

Chiappori, P.-A. (1988). Rational household labor supply. Econometrica 56, 63-89.

Chiappori, P.-A. (1992). Collective labor supply and welfare. Journal of Political Economy 100, 437-467.

Clark, A. E. (2001). What really matters in a job? Hedonic measurement using quit data. Labour Economics 8(2), 223-242.

Clark, A. E., P. Frijters, and M. A. Shields (2008). Relative income, happiness, and utility: an explanation for the Easterlin paradox and other puzzles. Journal of Economic Literature 46, 95-144.

Contoyannis, P. and A. M. Jones (2004). Socio-economic status, health and lifestyle. Journal of Health Economics 23(5), 965-995.

Cummins, R., A. Lau, and M. Davern (2008). Homeostatic mechanisms and subjective wellbeing. In K. Land (Ed.), Handbook of Social Indicators and Quality of Life Studies. New York London: Springer.

Davern, M., R. Cummins, and M. Stokes (2007). Subjective wellbeing as an affectivecognitive construct. Journal of Happiness Studies 8, 429-449. 
Freeman, R. B. (1978). Job satisfaction as an economic variable. American Economic Review 68(2), 135-141.

Frimmel, W., M. Halla, and R. Winter-Ebmer (2009). Assortative mating and divorce: Evidence from Austrian register data. Discussion Paper 4446, IZA, Bonn.

Fujita, F. and E. Diener (2005). Life satisfaction set point: Stability and change. Journal of Personality and Social Psychology 88(1), 158-164.

Gardner, J. and A. J. Oswald (2002). Is it money or marriage that keeps people alive? Annual Conference Paper 161, Royal Economic Society.

Gardner, J. and A. J. Oswald (2005). Do divorcing couples become happier by breaking up? Discussion Paper 1788, IZA, Bonn.

Gove, W., M. Hughes, and C. Briggs Style (1983). Does marriage have positive effects on the psychological well-being of the individual? Journal of Health and Social Behavior $24(2), 122-131$.

Headey, B. and A. Wearing (1992). Understanding happiness: a theory of subjective well-being. Melbourne: Longman Cheshire.

Hu, Y. and N. Goldman (1990). Mortality differentials by marital status: An international comparison. Demography 27(2), 233-250.

Kahneman, D., P. P. Wakker, and R. Sarin (1997). Back to Bentham? Explorations of experienced utility. Quarterly Journal of Economics 112(2), 375-405.

Kalmijn, M. (1994). Assortative mating by cultural and economic occupational status. American Journal of Sociology 100(2), 422-452.

Kalmijn, M., P. M. de Graaf, and J. P. G. Janssen (2005). Intermarriage and the risk of divorce in the Netherlands: The effects of differences in religion and in nationality, 1974-94. Population Studies 59(1), 71-85.

Kraft, K. and S. Neimann (2009). Effect of labor division between wife and husband on the risk of divorce: Evidence from German data. Discussion Paper 4515, IZA, Bonn.

Kristensen, N. and N. Westergard-Nielsen (2006). Job satisfaction and quits-which job characteristics matters most? Nationalokonomisk Tidsskrift 144(2), 230-248.

Lehrer, E. L. and C. U. Chiswick (1993). Religion as a determinant of marital stability. Demography 30(3), 385-404. 
Lykken, D. and A. Tellegen (1996). Happiness is a stochastic phenomenon. Psychological Science 7(3), 186-189.

Powdthavee, N. (2004). Testing for utility interdependence in marriage: evidence from panel data. The Warwick Economics Research Paper Series, University of Warwick, Department of Economics.

Powdthavee, N. (2009). I can't smile without you: Spousal correlation in life satisfaction. Journal of Economic Psychology 30(4), 675-689.

Sandvik, E., E. Diener, and L. Seidlitz (1993). Subjective well-being: The convergence and stability of self and non self report measures. Journal of Personality 61, 317-342.

Schimmack, U. and R. Lucas (2007). Marriage matters: Spousal similarity in life satisfaction. Schmollers Jahrbuch: Zeitschrift für Wirtschafts- und Sozialwissenschaften/Journal of Applied Social Science Studies 127(1), 105-111.

Senik, C. (2009). Direct evidence on income comparisons and their welfare effects. Journal of Economic Behavior and Organization 72(1), 408-424.

Smock, P., W. D. Manning, and S. Gupta (1999). The effect of marriage and divorce on women's economic well-being. American Sociological Review 64(6), 794-812.

South, S. and K. M. Lloyd (1995). Spousal alternatives and marital dissolution. American Sociological Review 60(1), 21-35.

Stauder, J. (2005). Familiengründung, eheliche Arbeitsteilung und eheliche Instabilität. In A. Tölke and K. Hank (Eds.), Männer: Das "vernachlässigte" Geschlecht in der Familienforschung, pp. 198-219. Wiesbaden: VS Verlag für Sozialwissenschaften.

Stutzer, A. and B. S. Frey (2006). Does marriage make people happy, or do happy people get married? Journal of Socio-Economics 35(2), 326-347.

Weiss, Y. (1997). The formation and dissolution of families: Why marry? Who marries whom? And what happens upon divorce? In Y. Weiss, M. R. Rosenzweig, and O. Stark (Eds.), Handbook of population and family economics. Volume 1A, pp. 81123. Handbooks in Economics, vol. 14. Amsterdam; New York and Oxford: Elsevier Science, North-Holland.

Weiss, Y. and R. J. Willis (1997). Match quality, new information, and marital dissolution. Journal of Labor Economics 15(1), S293-329. 
Wilson, C. M. and A. J. Oswald (2005). How does marriage affect physical and psychological health? A survey of the longitudinal evidence. The Warwick Economics Research Paper Series, University of Warwick, Department of Economics.

Zimmermann, A. C. and R. A. Easterlin (2006). Happily ever after? Cohabitation, marriage, divorce, and happiness in Germany. Population and Development Review 32(3), $511-528$. 


\section{Appendix}

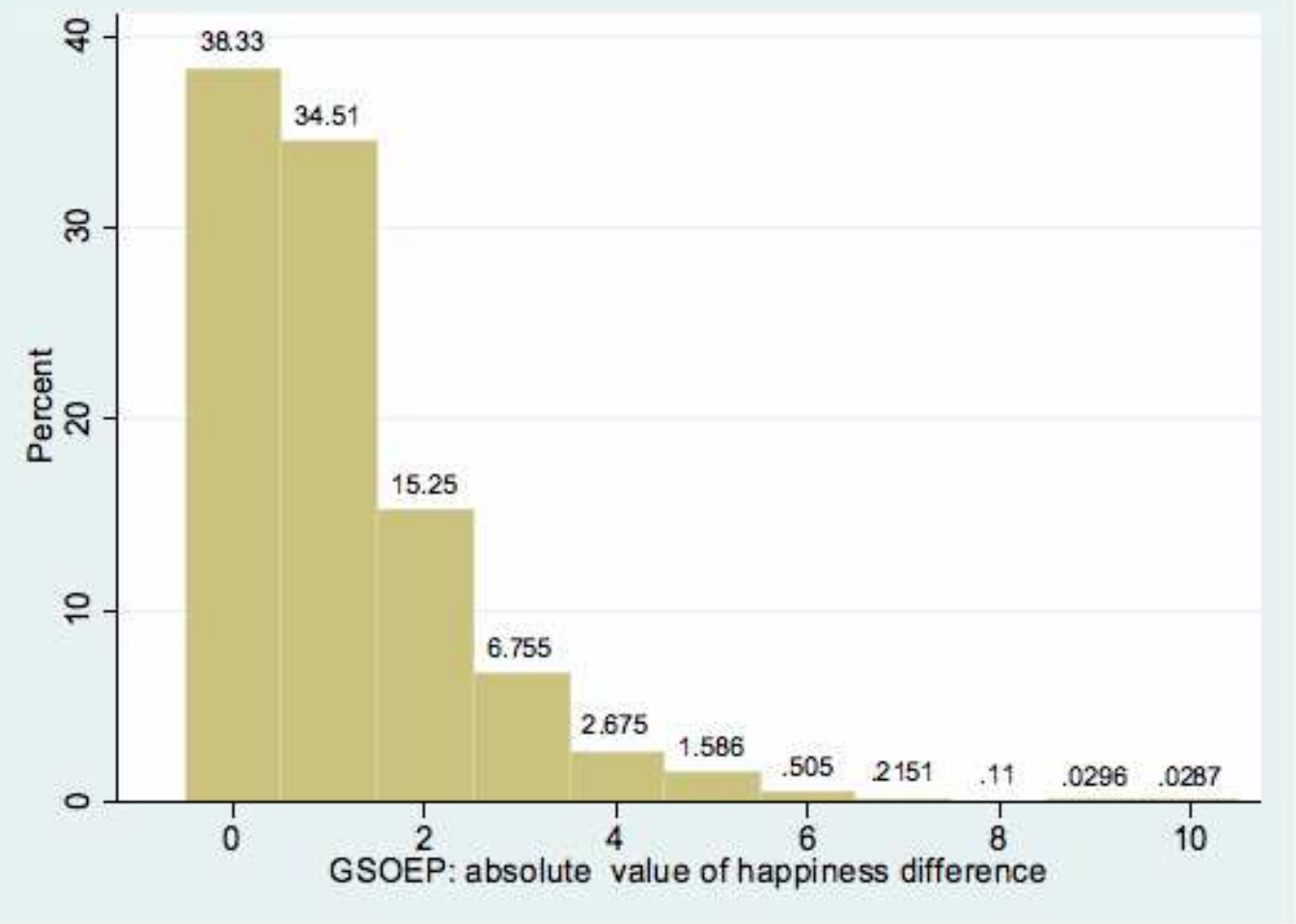

Figure 1: GSOEP. Absolute value of the happiness gap between spouses. 1984-2007 


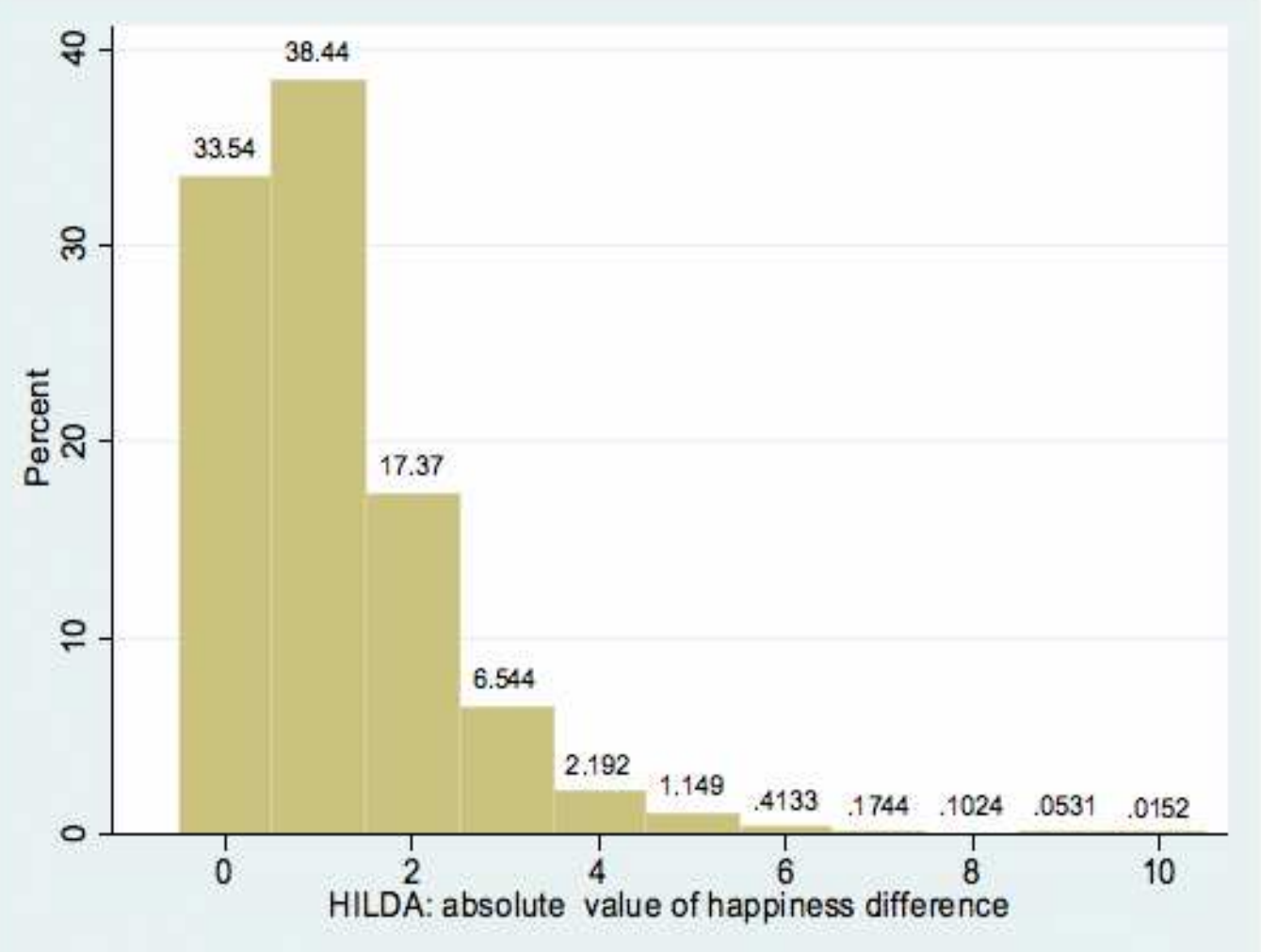

Figure 2: HILDA. Absolute value of the happiness gap between spouses. 2001-2007 


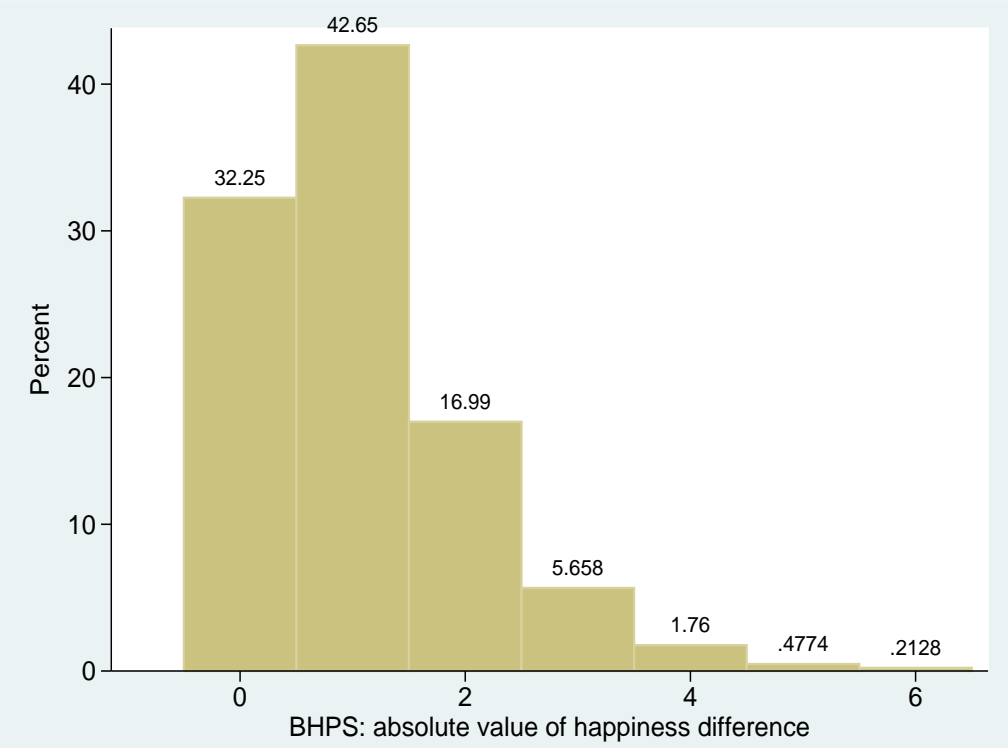

Figure 3: BHPS. Absolute value of the happiness gap between spouses. 1996-2007 


\section{Summary statistics}

Table 4: GSOEP. Summary statistics

\begin{tabular}{|c|c|c|c|c|c|c|}
\hline \multirow[b]{2}{*}{ Variable } & \multicolumn{3}{|c|}{ Men } & \multicolumn{3}{|c|}{ Women } \\
\hline & Mean & SD & $\mathbf{N}$ & Mean & SD & $\mathbf{N}$ \\
\hline Happiness & 7.03 & 1.79 & 125622 & 7.07 & 1.80 & 127334 \\
\hline Happiness difference & -0.04 & 1.67 & 121720 & 0.04 & 1.67 & 121720 \\
\hline Age & 48.65 & 14.51 & 125621 & 45.74 & 14.32 & 127333 \\
\hline Log household income & 7.75 & 0.50 & 118308 & 7.74 & 0.50 & 119936 \\
\hline Household size & 3.10 & 1.22 & 125622 & 3.10 & 1.22 & 127334 \\
\hline Number of children & 0.75 & 1.02 & 125622 & 0.75 & 1.02 & 127334 \\
\hline Working full-time & 0.68 & 0.02 & 85302 & 0.28 & 0.01 & 35237 \\
\hline Working part-time & 0.02 & 0.01 & 1726 & 0.19 & 0.02 & 24229 \\
\hline Vocational training & 0.001 & 0.01 & 462 & 0.01 & 0.01 & 791 \\
\hline Irregular part-time & 0.01 & 0.01 & 1392 & 0.05 & 0.01 & 6133 \\
\hline Not working & 0.29 & 1.67 & 36739 & 0.48 & 0.01 & 60939 \\
\hline Education years & 11.87 & 2.71 & 123778 & 2.33 & 2.50 & 125146 \\
\hline$<$ high school completed & 0.17 & 0.01 & 20680 & 0.28 & 0.01 & 35300 \\
\hline High school completed & 0.62 & 0.01 & 77595 & 0.57 & 0.01 & 71338 \\
\hline$>$ high school completed & 0.21 & 0.01 & 25938 & 0.15 & 0.01 & 18975 \\
\hline Annual working hours & 1649.08 & 1117.80 & 125621 & 892.74 & 964.03 & 127333 \\
\hline Housework hours per week & 2.52 & 2.67 & 114117 & 8.91 & 4.63 & 124377 \\
\hline Housework hours per week difference & -6.31 & 5.31 & 110945 & 6.31 & 5.31 & 110945 \\
\hline Age at marriage & 30.61 & 6.43 & 1006 & 27.90 & 5.91 & 1069 \\
\hline Height in $\mathrm{cm}$ & 177.45 & 7.16 & 22484 & 165.27 & 6.31 & 22964 \\
\hline BMI & 26.79 & 3.79 & 22466 & 25.21 & 4.67 & 22868 \\
\hline Annual doctor visits & 9.68 & 17.61 & 116093 & 11.48 & 17.59 & 117745 \\
\hline Very good health & 0.01 & 0.01 & 7286 & 0.01 & 0.00 & 7301 \\
\hline Good health & 0.41 & 0.02 & 37605 & 0.41 & 0.00 & 37860 \\
\hline Satisfactory health & 0.35 & 0.02 & 31524 & 0.34 & 0.01 & 31613 \\
\hline Poor health & 0.13 & 0.01 & 11560 & 0.14 & 0.01 & 12967 \\
\hline Bad health & 0.04 & 0.00 & 3170 & 0.04 & 0.01 & 3008 \\
\hline Germany born & 0.81 & 0.01 & 101419 & 0.83 & 0.01 & 103866 \\
\hline Both spouses Germany born & 0.77 & 0.01 & 96023 & 0.76 & 0.01 & 96766 \\
\hline Importance of family & 3.83 & 0.39 & 17102 & 3.87 & 0.35 & 17317 \\
\hline
\end{tabular}

Note: This table shows the summary statistics of variables for respondents who were surveyed in the GSOEP from 1984 to 2007 and who have a partner at time t. Means are reported for the continuous variables and proportions are reported for categorical variables. 
Table 5: HILDA. Summary statistics

\begin{tabular}{|c|c|c|c|c|c|c|}
\hline \multirow[b]{2}{*}{ Variable } & \multicolumn{3}{|c|}{ Men } & \multicolumn{3}{|c|}{ Women } \\
\hline & Mean & $\mathrm{SD}$ & $\mathbf{N}$ & Mean & $\mathrm{SD}$ & $\mathbf{N}$ \\
\hline Happiness & 7.92 & 1.48 & 29199 & 8.01 & 1.51 & 33341 \\
\hline Happiness difference & -0.12 & 1.61 & 18895 & 0.12 & 1.61 & 19461 \\
\hline Age & 43.33 & 17.78 & 30214 & 43.53 & 17.94 & 34269 \\
\hline Log household income & 5.83 & 0.70 & 30070 & 5.75 & 0.73 & 34099 \\
\hline Household size & 2.94 & 1.47 & 30214 & 2.92 & 1.47 & 34269 \\
\hline Number of children & 1.68 & 1.54 & 18301 & 1.85 & 1.54 & 21053 \\
\hline Employed & 0.71 & 0.02 & 20733 & 0.58 & 0.01 & 19159 \\
\hline Unemployed & 0.04 & 0.01 & 1044 & 0.03 & 0.02 & 1010 \\
\hline Not in the labor force & 0.26 & 1.67 & 7433 & 0.40 & 0.01 & 13186 \\
\hline$<$ high school completed & 0.30 & 0.01 & 8945 & 0.41 & 0.01 & 13917 \\
\hline High school completed & 0.13 & 0.01 & 3793 & 0.15 & 0.01 & 5067 \\
\hline$>$ high school completed & 0.58 & 0.01 & 17463 & 0.45 & 0.01 & 15279 \\
\hline Weekly working hours & 42.41 & 15.18 & 20713 & 30.76 & 15.24 & 19135 \\
\hline Housework hours per week & 6.01 & 6.91 & 22583 & 16.57 & 14.13 & 26059 \\
\hline Housework hours per week difference & -13.78 & 15.89 & 14433 & 13.88 & 15.85 & 14750 \\
\hline Age at marriage & 39.10 & 14.81 & 622 & 36.01 & 13.65 & 657 \\
\hline Very good health & 0.13 & 0.01 & 3399 & 0.11 & 0.00 & 3634 \\
\hline Good health & 0.36 & 0.02 & 9756 & 0.37 & 0.00 & 11488 \\
\hline Satisfactory health & 0.36 & 0.02 & 9561 & 0.35 & 0.01 & 11003 \\
\hline Poor health & 0.14 & 0.01 & 3694 & 0.14 & 0.01 & 4305 \\
\hline Bad health & 0.03 & 0.00 & 842 & 0.03 & 0.01 & 899 \\
\hline Australian born & 0.78 & 0.01 & 22715 & 0.66 & 0.01 & 6494 \\
\hline Both spouses Australian born & 0.66 & 0.01 & 12428 & 0.76 & 0.01 & 12833 \\
\hline Importance of family & 9.38 & 1.31 & 4963 & 9.66 & 0.97 & 5642 \\
\hline
\end{tabular}

Note: This table shows the summary statistics of variables for respondents who were surveyed in the HILDA from 2001 to 2007 and who have a partner at time t. Means are reported for the continuous variables and proportions are reported for categorical variables. 
Table 6: BHPS. Summary statistics

\begin{tabular}{|c|c|c|c|c|c|c|}
\hline \multirow[b]{2}{*}{ Variable } & \multicolumn{3}{|c|}{ Men } & \multicolumn{3}{|c|}{ Women } \\
\hline & Mean & SD & $\mathbf{N}$ & Mean & SD & $\mathbf{N}$ \\
\hline Life satisfaction & 5.23 & 1.16 & 36866 & 5.30 & 1.23 & 42399 \\
\hline Satisfaction difference (own - spouse) & -0.05 & 1.44 & 34981 & 0.04 & 1.45 & 36454 \\
\hline Age & 43.55 & 11.57 & 42200 & 42.44 & 11.90 & 48527 \\
\hline Log real monthly personal income & 7.35 & 1.07 & 41423 & 6.60 & 1.11 & 47178 \\
\hline Household size & 3.25 & 1.23 & 42200 & 3.24 & 1.23 & 48527 \\
\hline Number of children $($ aged $<16$ ) & 0.81 & 1.04 & 42199 & 0.80 & 1.04 & 48526 \\
\hline Male & 1.00 & 0.00 & 42200 & 0.00 & 0.00 & 48527 \\
\hline Paid employment & 0.69 & 0.46 & 42181 & 0.62 & 0.49 & 48505 \\
\hline Self-employed & 0.15 & 0.35 & 42181 & 0.05 & 0.21 & 48505 \\
\hline Unemployed & 0.04 & 0.19 & 42181 & 0.02 & 0.14 & 48505 \\
\hline Retired & 0.06 & 0.23 & 42181 & 0.07 & 0.26 & 48505 \\
\hline Maternity leave & 0.05 & 0.22 & 42181 & 0.04 & 0.20 & 48505 \\
\hline Family care & 0.00 & 0.01 & 42181 & 0.01 & 0.11 & 48505 \\
\hline Full-time student & 0.01 & 0.08 & 42181 & 0.17 & 0.38 & 48505 \\
\hline Disabled, long-term sickness & 0.01 & 0.07 & 42181 & 0.01 & 0.10 & 48505 \\
\hline Government training scheme & 0.00 & 0.02 & 42181 & 0.00 & 0.02 & 48505 \\
\hline Other type of employment & 0.00 & 0.06 & 42181 & 0.00 & 0.07 & 48505 \\
\hline Years of schooling & 10.15 & 1.13 & 41025 & 10.18 & 1.16 & 46664 \\
\hline Less than first degree & 0.84 & 0.37 & 41644 & 0.86 & 0.35 & 47921 \\
\hline Completed first degree & 0.12 & 0.33 & 41644 & 0.12 & 0.32 & 47921 \\
\hline Completed higher degree & 0.04 & 0.19 & 41644 & 0.03 & 0.16 & 47921 \\
\hline Maternity leave & 0.05 & 0.22 & 42181 & 0.04 & 0.20 & 48505 \\
\hline Government training scheme & 0.00 & 0.02 & 42181 & 0.00 & 0.02 & 48505 \\
\hline Other type of employment & 0.00 & 0.06 & 42181 & 0.00 & 0.07 & 48505 \\
\hline Hours normally worked per week & 26.73 & 19.54 & 42094 & 18.12 & 16.33 & 48415 \\
\hline Hours per week on housework & 5.54 & 5.70 & 41817 & 17.10 & 11.11 & 47954 \\
\hline Diff. in hours of housework (own minus spouse) & -11.41 & 12.99 & 39621 & 11.45 & 13.01 & 41337 \\
\hline Age at marriage & 25.40 & 5.10 & 15211 & 23.37 & 4.67 & 17622 \\
\hline Height in centimeters & 177.91 & 7.29 & 6432 & 162.56 & 6.54 & 8123 \\
\hline Body mass index & 27.10 & 4.48 & 6128 & 26.66 & 5.27 & 6307 \\
\hline No doctor visits & 0.34 & 0.48 & 42160 & 0.19 & 0.39 & 48478 \\
\hline One or two doctor visits & 0.39 & 0.49 & 42160 & 0.36 & 0.48 & 48478 \\
\hline Three to five doctor visits & 0.15 & 0.36 & 42160 & 0.22 & 0.42 & 48478 \\
\hline Six to ten doctor visits & 0.06 & 0.24 & 42160 & 0.11 & 0.32 & 48478 \\
\hline More than ten doctor visits & 0.05 & 0.22 & 42160 & 0.10 & 0.31 & 48478 \\
\hline Health: very poor & 0.02 & 0.12 & 38324 & 0.02 & 0.14 & 44107 \\
\hline Health: poor & 0.06 & 0.23 & 38324 & 0.07 & 0.26 & 44107 \\
\hline Health: fair & 0.18 & 0.38 & 38324 & 0.20 & 0.40 & 44107 \\
\hline Health: good & 0.47 & 0.50 & 38324 & 0.47 & 0.50 & 44107 \\
\hline Health: excellent & 0.27 & 0.45 & 38324 & 0.24 & 0.43 & 44107 \\
\hline Born in UK & 0.95 & 0.21 & 41895 & 0.95 & 0.23 & 48256 \\
\hline Both spouses born in UK & 0.92 & 0.27 & 39425 & 0.92 & 0.27 & 39286 \\
\hline Resp. looks after household money & 0.14 & 0.34 & 3434 & 0.25 & 0.43 & 3963 \\
\hline Partner looks after household money & 0.26 & 0.44 & 3434 & 0.13 & 0.33 & 3963 \\
\hline Respondent given household allowance & 0.01 & 0.08 & 3434 & 0.05 & 0.21 & 3963 \\
\hline Partner given household allowance & 0.04 & 0.19 & 3434 & 0.01 & 0.09 & 3963 \\
\hline Finances shared & 0.49 & 0.50 & 3434 & 0.49 & 0.50 & 3963 \\
\hline Finances maintained separately & 0.06 & 0.24 & 3434 & 0.07 & 0.25 & 3963 \\
\hline Importance of good partnership & 9.61 & 0.85 & 5959 & 9.65 & 0.89 & 6762 \\
\hline Importance of children & 7.81 & 2.66 & 5952 & 8.32 & 2.54 & 6757 \\
\hline Religion makes a difference & 0.27 & 0.44 & 10967 & 0.37 & 0.48 & 12655 \\
\hline
\end{tabular}




\section{Assortative mating by happiness level in the first year of mar- riage}

Table 7: GSOEP. Assortative mating by happiness level in the first year of marriage.

\begin{tabular}{lrrr}
\hline & \multicolumn{3}{c}{ Husband's happiness } \\
Wife's happiness & $\mathbf{1}$ & $\mathbf{2}$ & $\mathbf{3}$ \\
\hline 1 & 29.27 & 48.78 & 21.95 \\
2 & 4.07 & 61.05 & 34.88 \\
3 & 1.75 & 28.55 & 69.7 \\
\hline
\end{tabular}

Note: 1 if self-declared happiness $<5 ; 2$ if happiness $=5,6,7 ; 3$ if happiness $>7.69 .7 \%$ of women in the highest happiness group are married with men in the same group (in their first year of marriage).

Table 8: HILDA. Assortative mating by happiness level in the first year of marriage.

\begin{tabular}{lrrr}
\hline & \multicolumn{3}{c}{ Husband's happiness } \\
Wife's happiness & $\mathbf{1}$ & $\mathbf{2}$ & $\mathbf{3}$ \\
\hline 1 & 16.13 & 67.73 & 16.13 \\
2 & 6.31 & 68.20 & 35.49 \\
3 & 3.70 & 43.92 & 52.98 \\
\hline
\end{tabular}

Note: 1 if self-declared happiness $<6 ; 2$ if happiness $=7,8 ; 3$ if happiness $>8$. $16.13 \%$ of women in the lowest happiness group are married with men in the same group (in their first year of marriage).

Table 9: BHPS. Assortative mating by happiness level in the first year of marriage.

\begin{tabular}{lrrr}
\hline & \multicolumn{3}{c}{ Husband's happiness } \\
Wife's happiness & $\mathbf{1}$ & $\mathbf{2}$ & $\mathbf{3}$ \\
\hline 1 & 21.86 & 50.61 & 27.53 \\
2 & 9.6 & 47.95 & 42.45 \\
3 & 4.08 & 35.36 & 60.55 \\
\hline
\end{tabular}

Note: 1 if self-declared happiness $<4 ; 2$ if happiness $=4.5 ; 3$ if happiness $>6.7 .47 .95 \%$ of women in the intermediate happiness group are married with men in the same group (in their first year of marriage). 


\section{Correlates of the happiness gap}

Table 10: GSOEP. Correlates of the happiness gap

\begin{tabular}{|c|c|c|c|c|c|c|}
\hline \multirow[b]{2}{*}{ Variable } & \multicolumn{3}{|c|}{ W less happy than $M$} & \multicolumn{3}{|c|}{ W happier than $M$} \\
\hline & Mean & SD & $\mathbf{N}$ & Mean & SD & $\mathbf{N}$ \\
\hline Happiness & 5.93 & 1.84 & 75098 & 7.72 & 1.48 & 75094 \\
\hline Happiness difference & -1.78 & 1.17 & 75098 & 1.78 & 1.17 & 75094 \\
\hline Age & 47.02 & 14.27 & 75098 & 46.84 & 14.36 & 75094 \\
\hline Log household income & 7.75 & 0.50 & 118308 & 7.74 & 0.50 & 119936 \\
\hline Household size & 3.10 & 1.22 & 125622 & 3.10 & 1.22 & 127334 \\
\hline Number of children & 0.75 & 1.02 & 125622 & 0.75 & 1.02 & 127334 \\
\hline Working full-time & 0.68 & 0.02 & 85302 & 0.28 & 0.01 & 35237 \\
\hline Working part-time & 0.02 & 0.01 & 1726 & 0.19 & 0.02 & 24229 \\
\hline Vocational training & 0.001 & 0.01 & 462 & 0.01 & 0.01 & 791 \\
\hline Irregular part-time & 0.01 & 0.01 & 1392 & 0.05 & 0.01 & 6133 \\
\hline Not working & 0.29 & 1.67 & 36739 & 0.48 & 0.01 & 60939 \\
\hline Education years & 11.28 & 2.48 & 35583 & 11.37 & 2.49 & 38225 \\
\hline$<$ high school completed & 0.29 & 0.01 & 10434 & 0.28 & 0.01 & 10614 \\
\hline High school completed & 0.57 & 0.01 & 20158 & 0.57 & 0.01 & 21797 \\
\hline$>$ high school completed & 0.14 & 0.01 & 5114 & 0.16 & 0.01 & 5967 \\
\hline Annual working hours & 858.00 & 964.21 & 36184 & 934.67 & 962.59 & 38940 \\
\hline Housework hours per week & 9.01 & 4.86 & 35286 & 8.95 & 4.67 & 38103 \\
\hline Housework hours per week difference & 6.19 & 5.58 & 32929 & 6.34 & 5.27 & 35491 \\
\hline Age at marriage & 27.80 & 6.25 & 272 & 27.42 & 5.40 & 328 \\
\hline Height in $\mathrm{cm}$ & 165.12 & 6.32 & 6494 & 165.20 & 6.36 & 6987 \\
\hline BMI & 25.36 & 4.75 & 6464 & 25.21 & 4.75 & 6960 \\
\hline Annual doctor visits & 14.12 & 21.63 & 33396 & 10.06 & 15.19 & 36068 \\
\hline Very good health & 0.05 & 0.01 & 1258 & 0.10 & 0.01 & 2799 \\
\hline Good health & 0.33 & 0.02 & 8502 & 0.41 & 0.45 & 12786 \\
\hline Satisfactory health & 0.35 & 0.02 & 9234 & 0.33 & 0.01 & 9389 \\
\hline Poor health & 0.21 & 0.01 & 5362 & 0.10 & 0.01 & 2942 \\
\hline Bad health & 0.07 & 0.00 & 1744 & 0.02 & 0.01 & 449 \\
\hline Germany born & 0.83 & 0.01 & 29692 & 0.83 & 0.01 & 31851 \\
\hline Both spouses Germany born & 0.96 & 0.01 & 30355 & 0.96 & 0.01 & 28345 \\
\hline Importance of family & 3.86 & 0.38 & 4968 & 3.88 & 0.33 & 5215 \\
\hline
\end{tabular}

Note: This table shows the summary statistics of variables for respondents who were surveyed in the GSOEP from 1984 to 2007 and who have a partner at time t. Means are reported for the continuous variables and proportions are reported for categorical variables. 
Table 11: HILDA. Correlates of the happiness gap

\begin{tabular}{|c|c|c|c|c|c|c|}
\hline \multirow[b]{2}{*}{ Variable } & \multicolumn{3}{|c|}{ Men } & \multicolumn{3}{|c|}{ Women } \\
\hline & Mean & $\mathrm{SD}$ & $\mathbf{N}$ & Mean & $\mathrm{SD}$ & $\mathbf{N}$ \\
\hline Happiness & 7.00 & 1.45 & 7932 & 8.79 & 1.05 & 9644 \\
\hline Happiness difference & -1.69 & 1.07 & 7932 & 1.69 & 1.07 & 9644 \\
\hline Age & 45.30 & 14.92 & 7932 & 44.55 & 14.47 & 9644 \\
\hline Log household income & 5.92 & 0.63 & 7889 & 5.95 & 0.61 & 9613 \\
\hline Household size & 3.15 & 1.29 & 7932 & 3.23 & 1.33 & 9644 \\
\hline Number of children & 2.05 & 1.40 & 5369 & 2.10 & 1.41 & 6455 \\
\hline Employed & 0.60 & 0.02 & 4789 & 0.59 & 0.01 & 5682 \\
\hline Unemployed & 0.03 & 0.01 & 207 & 0.02 & 0.02 & 208 \\
\hline Not in the labor force & 0.37 & 1.67 & 2936 & 0.39 & 0.01 & 3754 \\
\hline$<$ high school completed & 0.37 & 0.01 & 3003 & 0.39 & 0.01 & 3799 \\
\hline High school completed & 0.14 & 0.01 & 1112 & 0.15 & 0.01 & 1419 \\
\hline$>$ high school completed & 0.48 & 0.01 & 3813 & 0.46 & 0.01 & 4423 \\
\hline Weekly working hours & 32.26 & 14.69 & 4784 & 31.00 & 14.76 & 5675 \\
\hline Housework hours per week & 19.12 & 14.35 & 6107 & 19.58 & 14.67 & 7442 \\
\hline Housework hours per week difference & 12.73 & 15.89 & 5835 & 14.06 & 16.24 & 7116 \\
\hline Age at marriage & 35.49 & 13.73 & 231 & 35.11 & 12.69 & 310 \\
\hline Very good health & 0.08 & 0.00 & 543 & 0.14 & 0.01 & 1238 \\
\hline Good health & 0.32 & 0.00 & 2330 & 0.40 & 0.02 & 3575 \\
\hline Satisfactory health & 0.38 & 0.01 & 2787 & 0.34 & 0.02 & 3007 \\
\hline Poor health & 0.17 & 0.01 & 1240 & 0.10 & 0.01 & 901 \\
\hline Bad health & 0.05 & 0.01 & 354 & 0.02 & 0.00 & 168 \\
\hline Australian born & 0.76 & 0.01 & 6044 & 0.75 & 0.01 & 7221 \\
\hline Both spouses Australian born & 0.81 & 0.01 & 12428 & 0.81 & 0.01 & 12833 \\
\hline Importance of family & 9.65 & 0.93 & 1280 & 9.80 & 0.75 & 1565 \\
\hline
\end{tabular}

Note: This table shows the summary statistics of variables for respondents who were surveyed in the HILDA from 2001 to 2007 and who have a partner at time t. Means are reported for the continuous variables and proportions are reported for categorical variables. 
Table 12: BHPS. Correlates of the happiness gap

\begin{tabular}{|c|c|c|c|c|c|c|}
\hline \multirow[b]{2}{*}{ Variable } & \multicolumn{3}{|c|}{ W less happy than M } & \multicolumn{3}{|c|}{ W happier than $\mathrm{M}$} \\
\hline & Mean & SD & $\mathbf{N}$ & Mean & SD & $\mathbf{N}$ \\
\hline Life satisfaction & 4.29 & 1.18 & 11724 & 5.98 & 0.89 & 12959 \\
\hline Happiness difference (own minus spouse) & -1.56 & 0.87 & 11724 & 1.53 & 0.84 & 12959 \\
\hline Age & 42.64 & 11.88 & 11724 & 42.15 & 12.02 & 12959 \\
\hline Log real monthly personal income & 6.60 & 1.10 & 11403 & 6.56 & 1.13 & 12594 \\
\hline Household size & 3.23 & 1.24 & 11724 & 3.24 & 1.22 & 12959 \\
\hline Number of children $($ aged $<16)$ & 0.79 & 1.04 & 11724 & 0.82 & 1.04 & 12959 \\
\hline Male & 0.00 & 0.00 & 11724 & 0.00 & 0.00 & 12959 \\
\hline Paid employment & 0.61 & 0.49 & 11719 & 0.61 & 0.49 & 12951 \\
\hline Self-employed & 0.04 & 0.20 & 11719 & 0.05 & 0.21 & 12951 \\
\hline Unemployed & 0.02 & 0.15 & 11719 & 0.02 & 0.13 & 12951 \\
\hline Retired & 0.07 & 0.26 & 11719 & 0.08 & 0.27 & 12951 \\
\hline Maternity leave & 0.06 & 0.24 & 11719 & 0.03 & 0.18 & 12951 \\
\hline Family care & 0.01 & 0.10 & 11719 & 0.02 & 0.12 & 12951 \\
\hline Full-time student & 0.17 & 0.37 & 11719 & 0.18 & 0.38 & 12951 \\
\hline Disabled, long-term sickness & 0.01 & 0.10 & 11719 & 0.01 & 0.11 & 12951 \\
\hline Government training scheme & 0.00 & 0.01 & 11719 & 0.00 & 0.02 & 12951 \\
\hline Other type of employment & 0.00 & 0.07 & 11719 & 0.01 & 0.07 & 12951 \\
\hline Years of schooling & 10.17 & 1.13 & 11338 & 10.15 & 1.17 & 12506 \\
\hline Less than first degree & 0.87 & 0.34 & 11571 & 0.86 & 0.34 & 12796 \\
\hline Completed first degree & 0.11 & 0.31 & 11571 & 0.11 & 0.31 & 12796 \\
\hline Completed higher degree & 0.02 & 0.15 & 11571 & 0.03 & 0.16 & 12796 \\
\hline Maternity leave & 0.06 & 0.24 & 11719 & 0.03 & 0.18 & 12951 \\
\hline Government training scheme & 0.00 & 0.01 & 11719 & 0.00 & 0.02 & 12951 \\
\hline Other type of employment & 0.00 & 0.07 & 11719 & 0.01 & 0.07 & 12951 \\
\hline Hours normally worked per week & 18.19 & 16.58 & 11695 & 17.83 & 16.25 & 12932 \\
\hline Hours per week on housework & 17.02 & 11.32 & 11588 & 17.36 & 11.20 & 12823 \\
\hline Diff. in hours of housework (own minus spouse) & 11.21 & 13.37 & 11512 & 11.98 & 13.03 & 12740 \\
\hline Age at marriage & 23.19 & 4.77 & 3922 & 23.52 & 4.70 & 4689 \\
\hline Height in centimeters & 162.29 & 6.55 & 2170 & 162.71 & 6.48 & 2334 \\
\hline Body mass index & 26.96 & 5.60 & 1684 & 26.69 & 5.38 & 1828 \\
\hline No doctor visits & 0.17 & 0.37 & 11712 & 0.21 & 0.41 & 12948 \\
\hline One or two doctor visits & 0.34 & 0.47 & 11712 & 0.38 & 0.49 & 12948 \\
\hline Three to five doctor visits & 0.24 & 0.42 & 11712 & 0.22 & 0.41 & 12948 \\
\hline Six to ten doctor visits & 0.13 & 0.34 & 11712 & 0.10 & 0.30 & 12948 \\
\hline More than ten doctor visits & 0.13 & 0.34 & 11712 & 0.09 & 0.29 & 12948 \\
\hline Health: very poor & 0.03 & 0.17 & 10514 & 0.01 & 0.11 & 11559 \\
\hline Health: poor & 0.11 & 0.31 & 10514 & 0.05 & 0.23 & 11559 \\
\hline Health: fair & 0.25 & 0.43 & 10514 & 0.18 & 0.38 & 11559 \\
\hline Health: good & 0.44 & 0.50 & 10514 & 0.48 & 0.50 & 11559 \\
\hline Health: excellent & 0.17 & 0.37 & 10514 & 0.27 & 0.45 & 11559 \\
\hline Born in UK & 0.95 & 0.23 & 11661 & 0.95 & 0.23 & 12890 \\
\hline Both spouses born in UK & 0.92 & 0.27 & 10916 & 0.92 & 0.27 & 12197 \\
\hline Resp. looks after household money & 0.27 & 0.45 & 1048 & 0.24 & 0.42 & 1140 \\
\hline Partner looks after household money & 0.13 & 0.34 & 1048 & 0.12 & 0.33 & 1140 \\
\hline Respondent given household allowance & 0.04 & 0.20 & 1048 & 0.06 & 0.24 & 1140 \\
\hline Partner given household allowance & 0.01 & 0.08 & 1048 & 0.01 & 0.11 & 1140 \\
\hline Finances shared & 0.47 & 0.50 & 1048 & 0.51 & 0.50 & 1140 \\
\hline Finances maintained separately & 0.07 & 0.25 & 1048 & 0.05 & 0.22 & 1140 \\
\hline Importance of good partnership & 9.60 & 0.98 & 1816 & 9.75 & 0.72 & 2069 \\
\hline Importance of children & 8.20 & 2.62 & 1816 & 8.51 & 2.41 & 2065 \\
\hline Religion makes a difference & 0.35 & 0.48 & 3190 & 0.35 & 0.48 & 3590 \\
\hline
\end{tabular}

Note: BHPS 1996-2007. The sample includes only women who live with a partner in t. Also, in this cross-table, women who report the same satisfaction level as their partner are dropped. 
Table 13: Lagged values of the absolute value of the happiness gap between spouses

\begin{tabular}{lrrr}
\hline Absolute value of the happiness gap & GSOEP & HILDA & BHPS \\
\hline 1 year lagged & 0.0016 & 0.0026 & -0.00062 \\
& $(0.0003)$ & $(0.0008)$ & $(0.00063)$ \\
2 years lagged & 0.0013 & 0.0032 & -0.00060 \\
& $(0.0003)$ & $(0.0008)$ & $(0.00069)$ \\
3 years lagged & 0.0010 & 0.0017 & 0.00081 \\
& $(0.0004)$ & $(0.0010)$ & $(0.00063)$ \\
4 years lagged & 0.0011 & 0.0019 & -0.0014 \\
& $(0.0004)$ & $(0.0014)$ & $(0.00089)$ \\
5 years lagged & 0.0007 & 0.0046 & 0.00044 \\
& $(0.0004)$ & $(0.0017)$ & $(0.0011)$ \\
\hline
\end{tabular}

Note: Each coefficient (each cell) corresponds to a separate regression, in which the indicated lagged happiness gap is introduced in addition to the current absolute value of the happiness gap, total happiness and the other usual controls (age, age difference, number of children, log household income). The standard errors are adjusted for clustering at the individual level. 


\section{Divorce and happiness gaps in the first year of marriage}

Table 14: GSOEP. Probit estimate of the probability that a separation is EVER observed in the survey. Female sample. Legally married couples.

\begin{tabular}{lrr}
\hline & Marg. eff. & $\mathbf{t}$ \\
\hline Absolute value of happiness difference & $\mathbf{0 . 0 2 3 7 7 5}$ & $\mathbf{1 . 7}$ \\
Total happiness & -0.000029 & 0.1 \\
Age & -0.001442 & 0.5 \\
Own age minus spouse age & -0.005222 & 1.3 \\
Number of children & 0.052937 & 2.2 \\
Log real monthly household income & -0.234742 & 5.5 \\
Pseudo R squared & 0.0467 & \\
Number of observations & 899 & \\
\hline
\end{tabular}

Note: Only married couples. Standard errors clustered at the individual level.

Table 15: HILDA. Probit estimate of the probability that a separation is EVER observed in the survey. Female sample. Legally married couples.

\begin{tabular}{lrr}
\hline & Marg. eff. & t \\
\hline Absolute value of happiness difference & $\mathbf{0 . 0 2 3 0 7 6}$ & $\mathbf{2 . 4}$ \\
Total happiness & -0.004078 & 0.6 \\
Age & 0.000474 & 0.4 \\
Own age minus spouse age & -0.001135 & 0.4 \\
Number of children & 0.009816 & 1.0 \\
Log real monthly household income & -0.026942 & 0.8 \\
Pseudo R squared & 0.0504 & \\
Number of observations & 434 & \\
\hline
\end{tabular}

Note: Only married couples. Standard errors clustered at the individual level. 
Table 16: BHPS. Probit estimate of the probability that a separation is EVER observed in the survey. Female sample. Legally married couples.

\begin{tabular}{lrr}
\hline & Marg. eff. & $\mathbf{t}$ \\
\hline Absolute value of happiness difference & $\mathbf{. 0 4 2 7 7}$ & $\mathbf{2 . 6}$ \\
Total happiness & -.02551 & -2.6 \\
Age & -.001982 & -1.1 \\
Own age minus spouse age & .0001699 & 0.1 \\
Number of children (aged $<16)$ & .02546 & 1.5 \\
Log real monthly household income & -.0613 & -2.2 \\
Pseudo R squared & 0.04 & \\
Number of observations & 845 & \\
\hline
\end{tabular}

Note: Only married couples. Standard errors clustered at individual level. 


\section{Fixed effect estimates of the probability to divorce}

Table 17: GSOEP. Xtlogit estimates of the probability to break-up next year. Female sample. Legally married couples.

\begin{tabular}{lrr}
\hline & Marg. eff. & t \\
\hline Own happiness $<$ spouse's happiness & $\mathbf{0 . 2 1 2 6 9 0}$ & $\mathbf{2 . 5}$ \\
Own happiness $>$ spouse's happiness & $\mathbf{- 0 . 0 0 7 4 7 2}$ & $\mathbf{0 . 2}$ \\
Total happiness & -0.210938 & 16.0 \\
Age & 0.235927 & 20.7 \\
Own age minus spouse age & -0.084382 & 2.7 \\
Number of children & -0.275478 & 3.5 \\
Log real monthly household income & -0.081417 & 0.8 \\
Log likelihood & -6680 & \\
Observations & 90381 & \\
Number of groups & 1189 & \\
Min. obs. per group & 2 & \\
Avg. obs. per group & \multicolumn{3}{c}{} \\
Max. obs. per group & 23 & \\
\hline
\end{tabular}

Note: Only married couples. Omitted reference category: own happiness $=$ spouse's happiness. Standard errors clustered at individual level.

Table 18: BHPS. Xtlogit estimates of the probability to break-up next year. Female sample. Legally married couples.

\begin{tabular}{lrr}
\hline & Coeff. & t \\
\hline Own happiness < spouse's happiness & $\mathbf{. 3 2 0 2}$ & $\mathbf{1 . 4}$ \\
Own happiness $>$ spouse's happiness & $\mathbf{. 1 2 7 9}$ & $\mathbf{0 . 6}$ \\
Total happiness & -.3356 & -5.5 \\
Age & .4563 & 9.5 \\
Own age minus spouse age & -.2879 & -4.7 \\
Number of children (aged $<16)$ & .2509 & 1.4 \\
Log real monthly household income & -.007731 & -0.0 \\
Log likelihood & -279.39 & \\
Observations & 1193 & \\
Number of groups & 264 & \\
Min. obs. per group & 2 & \\
Avg. obs. per group & 4.5 & \\
Max. obs. per group & 10 & \\
\hline
\end{tabular}

Note: Only married couples. Omitted reference category: own happiness $=$ spouse's happiness. Standard errors clustered at individual level. 


\section{Asymmetry}

Table 19: GSOEP. Probit estimate of the probability to break-up next year. Female sample. Only legally married couples.

\begin{tabular}{lrr}
\hline & Marg. eff. & $\mathbf{t}$ \\
\hline Own happiness $<$ spouse's happiness & $\mathbf{0 . 0 0 4 9 7 2}$ & $\mathbf{5 . 4}$ \\
Own happiness $>$ spouse's happiness & $\mathbf{0 . 0 0 0 3 0 4}$ & $\mathbf{0 . 3}$ \\
Total happiness & -0.001881 & 17.0 \\
Age & 0.000209 & 7.3 \\
Own age minus spouse age & -0.000416 & 4.7 \\
Number of children & 0.001129 & 2.7 \\
Log real monthly household income & -0.003237 & 4.1 \\
Pseudo R squared & 0.0374 & \\
Number of observations & 90381 & \\
\hline
\end{tabular}

Note: Only married couples. Omitted reference category: own happiness $=$ spouse's happiness. Standard errors clustered at the individual level.

Table 20: HILDA. Probit estimate of the probability to break-up next year. Female sample. Only legally married couples.

\begin{tabular}{lrr}
\hline & Marg. eff. & t \\
\hline Own happiness $<$ spouse's happiness & $\mathbf{0 . 0 0 4 0 6 2}$ & $\mathbf{1 . 9}$ \\
Own happiness $>$ spouse's happiness & $\mathbf{0 . 0 0 0 2 8 0}$ & $\mathbf{0 . 2}$ \\
Total happiness & -0.002779 & 7.3 \\
Age & -0.00053 & 6.5 \\
Own age minus spouse age & 0.000519 & 2.2 \\
Number of children & 0.002473 & 3.4 \\
Log real monthly household income & -0.004762 & 3.1 \\
Pseudo R squared & 0.0612 & \\
Number of observations & 16150 & \\
\hline
\end{tabular}

Note: Only married couples. Omitted reference category: own happiness $=$ spouse's happiness. Standard errors clustered at individual level. 
Table 21: BHPS. Probit estimate of the probability to break-up next year. Female sample. Only legally married couples

\begin{tabular}{lrr}
\hline & Marg. eff. & t \\
\hline Own happiness $<$ spouse's happiness & $\mathbf{. 0 0 2 7 7 7}$ & $\mathbf{2 . 1}$ \\
Own happiness $>$ spouse's happiness & $\mathbf{. 0 0 0 0 1 0 9}$ & $\mathbf{0 . 0}$ \\
Total happiness & -.002793 & -11.6 \\
Age & -.000585 & -12.1 \\
Own age minus spouse age & .0003519 & 2.8 \\
Number of children (aged $<16)$ & .0007222 & 1.7 \\
Log real monthly household income & -.001796 & -2.5 \\
Pseudo R squared & 0.11 & \\
Number of observations & 25246 & \\
\hline
\end{tabular}

Note: Only married couples. Omitted reference category: own happiness $=$ spouse's happiness. Standard errors clustered at individual level 